\title{
PENGEMBANGAN CD PEMBELAJARAN MATEMATIKA BERBANTUAN SOFTWARE GEOMETER'S SKETCHPAD DENGAN PENDEKATAN KONTRUKTIVISME BERBASIS TEORI JEAN PIAGET
}

\author{
Sutri Theo Lija Sidabutar \\ Universitas Katolik Santo Thomas, Medan; \\ sutrisdbtr@gmail.com
}

\begin{abstract}
Abstrak. Penelitian ini bertujuan untuk 1) mengetahui validitas $C D$ pembelajaran matematika berbantuan Software Geometer's Sketchpad dengan pendekatan Konstruktivisme berbasis teori Jean Piaget; 2) mengetahui efektifitas dari $C D$ pembelajaran matematika berbantuan Software Geometer's Sketchpad dengan pendekatan Konstruktivisme berbasis teori Jean Piaget. Metode yang digunakan dalam penelitian ini adalah penelitian dan pengembangan atau research and development $(R \mathcal{E} D)$ dengan model pengembangan ADDIE (Analysis, Design, Development, Implementation, Evaluation). Subjek penelitian ini yaitu kelas VIII-4 SMP St. Petrus Medan dengan jumlah 32 orang siswa. Jenis data yang digunakan adalah data kualitatif dan data kuantitatif. Berdasarkan pengolahan data dan pembahasan, diperoleh data hasil validasi ahli materi dengan persentase $85,4 \%$ berada pada kategori sangat valid, sedangkan hasil validasi ahli media dengan rata-rata persentase $87,3 \%$ berada pada kategori sangat valid sehingga CD pembelajaran matematika dikatakan sangat valid. Keefektifan CD pembelajaran matematika berbantuan software geometer's sketchpad dengan pendekatan konstruktivisme berbasis Teori Jean Piaget dapat dilihat dari beberapa penilaian sebagai berikut: 1) Respon positif yang dinilai oleh siswa dengan rata-rata persentase respon positif sebesar 88,88\% dengan kategori sangat positif, serta respon guru dengan rata-rata persentase $84 \%$ dengan kategori positif; 2) hasil observasi aktivitas guru dalam mengelola pembelajaran menggunakan CD pembelajaran matematika dengan rata-rata persentase sebesar $89,73 \%$ dengan kategori sangat baik dan hasil observasi aktivitas siswa dengan rata-rata persentase sebesar $86,66 \%$ dengan pada kategori sangat baik; 3 ) hasil tes hasil belajar siswa yaitu diperoleh ketuntasan klasikal sebesar 84,37\% dengan kategori sangat tinggi. Berdasarkan penilaian tersebut dapat disimpulkan bahwa penggunaan $\mathrm{CD}$ pembelajaran matematika berbantuan software
\end{abstract}

Cartesius: Jurnal Pendidikan Matematika Vol. 2, No. 2

CProdi Pendidikan Matematika Universitas Katolik Santo Thomas 
geometer's sketchpad dengan pendekatan konstruktivisme berbasis teori Jean Piaget valid dan efektif digunakan dalam proses pembelajaran.

Kata kunci: Software Geometer's Sketchpad, pendekatan konstruktivisme

\begin{abstract}
Abstrack. This study aims to 1) determine the validity of the Mathematics learning $C D$ assisted by Geometer's Sketchpad Software with Jean Piaget's theory-based Constructivism approach; 2) determine the effectiveness of the Mathematics Learning CD assisted by Geometer's Sketchpad Software with Jean Piaget's theory-based Constructivism approach. The method used in this research is research and development or research and development (RED) with the ADDIE development model (Analysis, Design, Development, Implementation, Evaluation). The subject of this research is grade VIII-4 SMP St. Petrus Medan with 32 students. The type of data used is qualitative data and quantitative data. Based on data processing and discussion, the data obtained from the material expert validation results with a percentage of $85.4 \%$ are in the category of very valid, while the results of the validation of media experts with an average percentage of $87.3 \%$ are in the category of very valid so that the mathematics learning $C D$ is said to be very valid. The effectiveness of mathematics learning $C D$ assisted by geometer's sketchpad software with constructivism approach based on Jean Piaget's Theory can be seen from the following assessments: 1) Positive responses assessed by students with an average percentage of positive responses of $88.88 \%$ with a very positive category, and responses teachers with an average percentage of $84 \%$ with a positive category; 2) the results of observations of teacher activities in managing learning using CDs learning mathematics with an average percentage of $89.73 \%$ with very good categories and the results of observations of student activities with an average percentage of $86.66 \%$ with very good categories; 3 ) the test results of student learning outcomes is obtained classical completeness of $84.37 \%$ with a very high category. Based on these assessments it can be concluded that the use of mathematics learning CDs assisted by geometer's sketchpad software with Jean Piaget's theory-based constructivism approach is valid and effective in the learning process.
\end{abstract}

Keywords. Geometer's Sketchpad software, constructivism approach

\title{
PENDAHULUAN
}

Perkembangan ilmu pengetahuan dan teknologi (IPTEK) tidak dapat dihindari lagi karena telah membawa dampak yang sangat besar di berbagai bidang, termasuk bidang pendidikan. Hal ini sesuai dengan pendapat Prasetyawan (2016: 26) menyatakan bahwa dunia pendidikan sudah Cartesius: Jurnal Pendidikan Matematika Vol. 2, No. 2

CProdi Pendidikan Matematika Universitas Katolik Santo Thomas 
dipengaruhi oleh perkembangan ilmu pengetahuan dan teknologi (IPTEK). Dalam bidang pendidikan, Kurniasari \& Qohar (2012: 1) menyatakan bahwa perkembangan IPTEK ini harus dimanfaatkan sebagai salah satu alat bantu atau media pembelajaran yang dapat digunakan dalam proses belajar mengajar. Dunia pendidikan dituntut oleh perkembangan ilmu pengetahuan dan teknologi untuk selalu menyesuaikan perkembangan teknologi terhadap usaha dan penyesuaian penggunaan teknologi dalam peningkatan mutu pendidikan khususnya pada pembelajaran matematika.

Pembelajaran matematika merupakan salah satu mata pelajaran yang telah diajarkan mulai dari jenjang pendidikan dasar hingga jenjang yang lebih tinggi. Suatu syarat untuk melanjutkan pendidikan ke jenjang berikutnya adalah pelajaran matematika. Sehingga hal ini tidak mengherankan bagi peserta didik jika pelajaran matematika adalah salah satu mata pelajaran yang di ujikan pada Ujian Nasional dari tingkat pendidikan dasar dan menengah.

Pendidikan matematika telah berkembang sangat pesat seiring dengan perkembangan ilmu pengetahuan dan teknologi (IPTEK). Melihat perkembangan ilmu pengetahuan dan teknologi maka bukan saatnya lagi seorang pendidik untuk memberikan pembelajaran secara konvensional (teacher center) dan hanya menggunakan metode ceramah atau hafalan dalam proses belajar mengajar. Sesuai dengan yang dikemukakan oleh Suprijono (dalam Posasi, 2015: 54) bahwa dalam proses belajar mengajar seorang pendidik/guru harus memiliki strategi pembelajaran yang memberikan bantuan atau fasilitas kepada siswa untuk mencapai tujuan pembelajaran Sehingga dapat disimpulkan bahwa seorang pendidik dapat memberikan strategi pembelajaran yang berbeda atau strategi yang menarik perhatian siswa dalam pembelajaran.

Suprijono dalam penelitiannya juga menyatakan bahwa dalam pembelajaran guru masih kurang mengembangkan kreativitas mereka dalam mengembangkan media pembelajaran dan pembelajaran masih berpusat pada guru khususnya pada pelajaran matematika. Sehingga mengakibatkan

Cartesius: Jurnal Pendidikan Matematika Vol. 2, No. 2

CProdi Pendidikan Matematika Universitas Katolik Santo Thomas 
siswa terlihat pasif, kurang kreatif, dan bosan dengan penyampaian materi yang monoton dalam pembelajaran matematika. Oleh karena itu, menurut jurnal penelitian Maharani \& Basir (2016: 33), menyatakan bahwa para guru dituntut harus mampu memanfaatkan dan mengembangkan teknologi yang berkembang saat ini yang telah disediakan oleh sekolah sebagai media pembelajaran yang kreatif, efektif dan efesien dalam menyampaikan materi kepada siswa sehingga pembelajaran matematika lebih dapat menarik perhatian siswa. Para guru juga dituntut untuk mengembangkan kreativitas dan keterampilan guru dalam membuat media pembelajaran untuk menciptakan media pembelajaran apabila media tersebut belum tersedia di sekolah.

Hal tersebut juga terjadi di SMP St. Petrus Medan. Berdasarkan hasil observasi pada tanggal 16 Januari 2019 dapat dilihat bahwa proses pembelajaran masih berpusat pada guru (Teacher Centered) dan penggunaan metode pembelajaran guru masih cenderung konvensional dan bersifat monoton. Guru masih cenderung menyampaikan materi dengan metode ceramah sehingga mengakibatkan siswa cenderung pasif, kurang kreatif, merasa bosan dalam proses pembelajaran. Selain observasi, dilakukan juga wawancara dengan guru matematika yaitu ibu Marietta Simbolon, S.Pd. Dari hasil wawancara, diperoleh informasi bahwa dalam memanfaatkan penggunaan media pembelajaran berbasis komputer masih minim digunakan terkhusus pada penggunaan software matematika yaitu Geometer's Sketchpad. Penggunaan CD pembelajaran matematika juga belum pernah digunakan dalam proses pembelajaran.

Permasalahan tersebut berakibat hasil belajar matematika siswa rendah. Hal tersebut dapat dilihat dari nilai UTS Sem. Genap Tahun 2018/2019 mata pelajaran matematika yang belum tuntas mencapai KKM yaitu 76 .

Cartesius: Jurnal Pendidikan Matematika Vol. 2, No. 2

CProdi Pendidikan Matematika Universitas Katolik Santo Thomas 
Tabel 1. Nilai Formatif Siswa Kelas VIII Tahun 2018/2019

\begin{tabular}{cccccc}
\hline No. & Kelas & $\begin{array}{c}\text { Jumlah } \\
\text { Siswa }\end{array}$ & $\begin{array}{c}\text { Nilai Rata- } \\
\text { Rata }\end{array}$ & $\begin{array}{c}\text { Pencapaian } \\
\text { KKM (\%) }\end{array}$ & KKM \\
\hline 1. & VIII - 1 & 34 & 46,0 & $29 \%$ & 76 \\
2. & VIII - 2 & 31 & 44,83 & $21 \%$ & \\
3. & VIII - 3 & 32 & 65,0 & $36 \%$ & \\
4. & VIII - 4 & 32 & 69,0 & $47 \%$ & \\
\hline
\end{tabular}

Sumber: SMP St. Petrus Medan 2018/2019

Proses pembelajaran tersebut harus diperbaiki. Upaya yang dilakukan adalah menggunakan pendekatan dan media pembelajaran yang tepat. Salah satu pendekatan pembelajaran tepat yaitu pendekatan konstruktivisme berbasis teori Jean Piaget dalam pembelajaran secara teori sangat efektif digunakan dalam proses belajar mengajar.

Dalam pendekatan konstruktivisme yang diutamakan adalah siswa harus lebih kreatif dan aktif dalam mengembangkan pengetahuan mereka berdasarkan pengalaman-pengalaman dan pengetahuan siswa itu sendiri sehingga siswa dapat berpikir lebih tinggi untuk menyelesaikan masalah. Selain itu, dalam teori Jean Piaget siswa SMP ada pada tahap perkembangan kognitif periode operasi formal, dimana siswa tersebut sudah mampu berpikir abstrak dan logis menggunakan pola pikir kemungkinan sehingga siswa dapat mengingat kembali pelajaran yang telah dipelajarinya atau mengembangkan pengetahuan sendiri sehingga siswa tidak merasa bosan dalam pembelajaran matematika. Salah satu alat yang mendukung dalam pembelajaran pendekatan konstruktivisme ini adalah media pembelajaran.

Gagne dan Brigg (dalam Arsyad, 2013: 3) secara implisit mengatakan bahwa media pembelajaran meliputi alat yang secara fisik digunakan untuk menyampaikan isi materi pengajaran, yang terdiri dari buku, tape recorder, kaset/CD, camera video, video recorder, film, slide (gambar bingkai), foto, gambar, grafik, televisi, dan komputer. Dengan demikian dapat disimpulkan bahwa media pembelajaran merupakan suatu media pembelajaran yang dapat digunakan oleh para guru untuk menyampaikan materi dalam proses

Cartesius: Jurnal Pendidikan Matematika Vol. 2, No. 2

CProdi Pendidikan Matematika Universitas Katolik Santo Thomas 
belajar mengajar sehingga dapat merangsang perhatian dan minat siswa dalam belajar".

Pengunaan media pembelajaran banyak memperoleh manfaat dalam proses pembelajaran seperti yang diungkapkan Edgar Dale yang dikutip oleh Latuheru (dalam Kurniasari \& Qohar, 2012: 2), yang mengatakan bahwa media pembelajaran baik digunakan dalam pembelajaran, maka manfaat media pembelajaran sebagai berikut: (1) perhatian siswa akan lebih tinggi terhadap materi yang dipelajari, (2) siswa dapat mendapatkan pengalaman yang nyata/konkret, (3) memotivasi atau mendorong siswa untuk selalu belajar secara mandiri (self activity), (4) siswa akan sulit melupakan hasil pelajaran yang telah dipelajarinya. Berdasarkan manfaat media pembelajaran yang diuraikan di atas memperlihatkan bahwa menggunakan media pembelajaran sangat penting dalam proses belajar mengajar. Salah satu cara untuk mengatasi kesulitan tersebut adalah dengan menggunakan media pembelajaran berbasis komputer. Media yang dapat digunakan dalam proses belajar mengajar adalah menggunakan CD (Compact Disk) pembelajaran interaktif terkhusus pembelajaran matematika.

Menurut Arsyad (2013: 38) mengatakan bahwa CD (Compact Disk) adalah “sistem penyimpanan dan rekaman video di mana signal audio - visual direkam pada disket plastik, bukan pada pita magnetik". CD (Compact Disk) pembelajaran video interaktif merupakan salah satu media dalam penyampaian materi video rekaman yang disimpan dalam CD dan disajikan dengan bantuan komputer sehingga siswa tidak hanya melihat video dan mendengarkan suara, tetapi siswa juga dapat memberikan respons yang aktif dan siswa dapat menerima materi dengan cepat

Penggunaan media CD pembelajaran ini sangat membantu guru dalam menyampaikan atau menjelaskan materi terhadap siswa dengan menggabungkan beberapa media seperti gambar, suara, animasi, video dan software geometer's sketchpad sesuai dengan materi geometri sehingga pembelajaran matematika lebih menarik. Media CD pembelajaran interaktif ini juga berisi materi, contoh soal, latihan soal yang berbantuan software

Cartesius: Jurnal Pendidikan Matematika Vol. 2, No. 2

CProdi Pendidikan Matematika Universitas Katolik Santo Thomas 
Geometer's Sketchpad. Media CD pembelajaran interaktif sudah banyak diminati dan disukai oleh siswa karena siswa tidak hanya belajar di sekolah saja, tetapi siswa bisa belajar sendiri dirumah. Dalam pembelajaran menggunakan CD interaktif sangat praktis karena dapat digunakan kapan dan dimanapun siswa berada tanpa dibatasi ruang dan waktu sehingga proses belajar mengajar akan lebih menarik dan tidak membosankan dan akan merangsang siswa untuk belajar matematika. Akan tetapi, penggunaan CD pembelajaran matematika yang menggunakan software masih jarang atau jumlahnya terbatas digunakan dalam pembelajaran matematika di sekolah.

Hamalik (dalam Prasetyawan, 2016: 4), mengemukakan bahwa penggunaan media pembelajaran dalam pembelajaran dapat membangkitkan motivasi dan merangsang minat siswa dalam proses belajar mengajar dan bahkan pengunaan media pembelajaran dapat mempengaruhi psikologis siswa. Penelitian yang relevan sebagai bukti bahwa CD pembelajaran sangat membantu guru dalam proses belajar mengajar dan menarik perhatian siswa dalam pembelajaran matematika banyak.

Salah satu penelitian yang diteliti oleh Maharani dan Basir (2016) dengan judul "Pengembangan Media CD Interaktif Matematika untuk Meningkatkan kemampuan Pemecahan Masalah Siswa SMP, menyimpulkan bahwa Pengembangan CD interaktif valid dan penggunaan CD interaktif dalam pembelajaran matematika terbukti praktis dan efektif untuk meningkatkan kemampuan pemecahan masalah siswa. Hal ini dimungkinkan karena siswa dapat belajar mandiri di rumah dan saat di kelas mereka dapat berperan aktif dalam kegiatan pembelajaran untuk memecahkan masalah yang ada pada CD interaktif. Mereka termotivasi dan merasa senang dengan tampilan CD interaktif yang menarik sehingga mereka tidak merasa bosan dalam belajar matematika. Hasil pengembangan CD interaktif ini tentunya masih terbatas pada materi prisma dan limas. Oleh karena itu, perlu dilakukan pengembangan CD interaktif untuk materi matematika yang lain".

Cartesius: Jurnal Pendidikan Matematika Vol. 2, No. 2

CProdi Pendidikan Matematika Universitas Katolik Santo Thomas 
Berdasarkan hasil penelitian di atas dapat disimpulkan bahwa penggunaan CD pada pembelajaran matematika sangat membantu guru dalam menyampaikan atau menjelaskan materi. Selain itu, penggunaan CD pembelajaran ini juga menarik perhatian siswa dalam belajar sehingga siswa lebih aktif, kreatif, tidak membosankan dalam pembelajaran. Siswa juga tidak hanya belajar di sekolah, tetapi juga bisa belajar mandiri di rumah karena CD pembelajaran dapat digunakan dimana dan kapan saja.

Berdasarkan uraian permasalahan diatas, penelitian ini penting karena sangat membantu guru dalam menyampaikan materi dalam pembelajaran dan menarik perhatian siswa, lebih aktif dan kreatif dalam pembelajaran matematika.

\section{METODE}

Metode penelitian ini menggunakan metode penelitian dan pengembangan media pembelajaran berupa CD pembelajaran matematika berbantuan Software geometer's sketchpad. Metode penelitian dan pengembangan ini menggunakan desain pengembangan model ADDIE. Model ini terdiri dari lima tahap utama, yaitu Analysis, Design, Development, Implementation, dan Evaluation.

Subjek penelitian ini adalah kelas VIII-4 SMP St. Petrus Medan pada semester genap tahun pelajaran 2018/2019 yang terdiri dari 32 siswa dimana siswa laki-laki berjumlah 17 orang dan perempuan 15 orang serta satu dosen ahli media dan satu dosen ahli materi.

Teknik pengumpulan data yang digunakan dalam penelitian ini adalah teknik tes dan non-tes. Tes yang digunakan adalah untuk mengetahui hasil belajar siswa. Sedangkan non-tes pada penelitian ini adalah lembar observasi kegiatan siswa dan guru serta lembar validasi yang diberikan kepada ahli media, ahli materi, respon guru dan respon siswa terhadap media pembelajaran.

Cartesius: Jurnal Pendidikan Matematika Vol. 2, No. 2

CProdi Pendidikan Matematika Universitas Katolik Santo Thomas 


\section{HASIL DAN PEMBAHASAN}

\section{Tahap Analysis (Analisis)}

Tahap pertama dalam penelitian pengembangan ini adalah analisis kebutuhan dan karakteristik siswa dengan melakukan observasi, wawancara dan nilai UTS Sem. Genap Tahun 2018/2019 di SMP St. Petrus Medan. Hasil analisis akan digunakan sebagai acuan pengembangan produk CD pembelajaran matematika berbantuan software geometer's sketchpad dengan pendekatan konstruktivisme berbasis teori Jean Piaget.

Berdasarkan hasil analisis kebutuhan tersebut dapat disimpulkan bahwa pengembangan CD pembelajaran matematika berbantuan software geometer's sketchpad pada materi lingkaran sangat diperlukan untuk meningkatkan proses pembelajaran yang menyenangkan sehingga dapat menarik perhatian siswa dan menumbuhkan motivasi belajar dan sikap siswa.

\section{Tahap Design (Perencanaan)}

Tahap perencanaan merupakan tindak lanjut dari tahap analisis. Pada proses perancangan (design) CD pembelajaran matematika pada materi lingkaran dibutuhkan sebuah sketsa desain untuk membantu pembuatan CD pembelajaran matematika materi lingkaran. Sketsa tersebut dituangkan dalam sebuah flowchart dan storyboard.

\section{Tahap Development (Pengembangan)}

1. Pembuatan CD pembelajaran matematika

Pembuatan CD pembelajaran matematika ini dilakukan dengan Microsoft Office Power Point. Isi dari CD pembelajaran matematika ini terdiri dari materi-materi yang didapatkan dari beberapa buku-buku Matematika kelas VIII SMP.

2. Validasi Kelayakan Produk

a. Validasi Ahli Materi

Setelah CD pembelajaran matematika selesai dibuat dilakukan validasi ahli materi. Validasi ahli materi digunakan untuk menilai materi yang telah disusun dalam CD pembelajaran matematika berbantuan software geometer's sketchpad dengan pendekatan konstruktivisme berbasis teori

Cartesius: Jurnal Pendidikan Matematika Vol. 2, No. 2

CProdi Pendidikan Matematika Universitas Katolik Santo Thomas 
Jean Piaget. Terdapat tiga aspek yaitu aspek pembelajaran, aspek materi, dan aspek bahasa. Dari hasil validasi materi diperoleh kesimpulan bahwa aspek pembelajaran, materi, dan bahasa materi diperoleh $85,45 \%$ yang termasuk ke dalam kategori sangat valid dan tidak perlu direvisi. Sehingga secara keseluruhan, media pembelajaran dengan menggunakan power point yang telah di kembangkan oleh peneliti dapat di uji cobakan.

\section{b. Validasi Ahli Media}

Validasi yang dilakukan oleh ahli media digunakan untuk menilai produk CD pembelajaran matematika. Aspek dalam CD pembelajaran memiliki 19 indikator. Penilaian ini bermaksud untuk melihat layak atau tidak CD pembelajaran matematika untuk diimplementasikan kepada siswa.

Dari hasil validasi media diperoleh kesimpulan bahwa aspek media CD pembelajaran yang termasuk kedalam kategori sangat valid dan tidak perlu revisi dengan persentase yang diperoleh $87,36 \%$. Sehingga secara keselurahan, CD pembelajaran matematika berbantuan software geometer's sketchpad dengan pendekatan konstruktivisme berbasis teori jean piaget yang telah dikembangkan oleh peneliti sangat baik untuk di ujicobakan.

\section{Tahap Implementation (Implementasi)}

Tahap ini adalah lanjutan dari tahap pengembangan. Pada tahap ini, semua rancangan media telah dikembangkan diterapkan setelah dilakukan revisi. CD pembelajaran matematika berbantuan software geometer's sketchpad dengan pendekatan konstruktivisme berbasis teori Jean Piaget yang telah dikembangkan, diimplementasikan pada situasi yang nyata yaitu di kelas. Namun dalam tahap ini, peneliti hanya sampai melakukan uji coba produk terhadap kelompok kecil (uji coba terbatas). Uji coba yang dimaksud untuk melihat tingkat keefektifan pada CD pembelajaran matematika tersebut. Uji coba terbatas terdiri dari 1 orang guru mata pelajaran matematika kelas VIII4 dan 32 orang siswa kelas VIII-4 SMP St. Petrus Medan.

Cartesius: Jurnal Pendidikan Matematika Vol. 2, No. 2

CProdi Pendidikan Matematika Universitas Katolik Santo Thomas 
Adapun keefektifan pengembangan $\mathrm{CD}$ pembelajaran matematika yang ditentukan berdasarkan lembar aktivitas guru dan siswa, respon guru dan siswa, dan tes hasil belajar. Berikut deskripsi keefektifan CD pembelajaran.

Tabel 2. Hasil Keseluruhan Keefektifan CD Pembelajaran

\begin{tabular}{|c|c|c|c|c|}
\hline No. & $\begin{array}{l}\text { Variabel Keefekti } \\
\text { Pembelajaran Mat }\end{array}$ & $\begin{array}{l}\text { fan CD } \\
\text { matika }\end{array}$ & Persentase & Kriteria \\
\hline 1. & $\begin{array}{l}\text { Lembar Observasi } \\
\text { Guru }\end{array}$ & Aktivitas & $89,22 \%$ & Sangat Baik \\
\hline 2. & $\begin{array}{l}\text { Lembar Observasi } \\
\text { Siswa }\end{array}$ & Aktivitas & $88,33 \%$ & Sangat Baik \\
\hline 3. & Tes Hasil Belajar & & $83,38 \%$ & Tuntas \\
\hline 4. & Angket Respon Guru & & $84 \%$ & Positif \\
\hline 5. & Angket Respon Siswa & & $88,88 \%$ & Positif \\
\hline
\end{tabular}

Berdasarkan tabel di atas dapat simpulkan bahwa CD pembelajaran matematika berbantuan software geometer's sketchpad dengan pendekatan konstruktivisme berbasis teori Jean Piaget dinyatakan efektif.

\section{Tahap Evaluation (Evaluasi)}

Evaluasi adalah tahap terakhir dari model pengembangan ADDIE. Pada tahap ini dilakukan evaluasi dari tahap analisis hingga tahap implementasi untuk mengetahui kevalidan dan keefektifan CD pembelajaran matematika berbantuan software geometer's sketchpad dengan pendekatan konstruktivime berbasis teori Jean Piaget. Berdasarkan hasil dari tahap analisis hingga tahap implementasi sudah memenuhi syarat kevalidan dan keefektifan CD pembelajaran matematika berbantuan software geometer's sketchpad dengan pendekatan konstruktivime berbasis teori Jean Piaget, maka CD pembelajaran matematika berbantuan software geometer's sketchpad dengan pendekatan konstruktivime berbasis teori Jean Piaget layak/valid dan efektif digunakan dalam proses pembelajaran matematika pada materi lingkaran.

\section{KESIMPULAN}

Berdasarkan hasil penelitian dan pengembangan $\mathrm{CD}$ pembelajaran matematika berbantuan software geometer's sketchpad dengan pendekatan konstruktivisme berbasis teori Jean Piaget, maka dapat disimpulkan bahwa:

Cartesius: Jurnal Pendidikan Matematika Vol. 2, No. 2

CProdi Pendidikan Matematika Universitas Katolik Santo Thomas 
1. CD pembelajaran matematika berbantuan software geometer's sketchpad dengan pendekatan konstruktivisme berbasis Teori Jean Piaget adalah sangat valid. Kevalidan CD pembelajaran matematika berbantuan software geometer's sketchpad dengan pendekatan konstruktivisme berbasis Teori Jean Piaget dapat dilihat dari hasil ahli materi dan ahli media. Hasil validasi ahli materi dengan rata-rata persentase $85,45 \%$, sedangkan hasil validasi ahli media dengan rata-rata persentase $87,36 \%$.

2. CD pembelajaran matematika berbantuan software geometer's sketchpad dengan pendekatan konstruktivisme berbasis Teori Jean Piaget adalah sangat efektif. Keefektifan CD pembelajaran matematika berbantuan software geometer's sketchpad dengan pendekatan konstruktivisme berbasis Teori Jean Piaget dapat dilihat dari beberapa penilaian yaitu: (1) Efektif karena CD pembelajaran matematika berbantuan software geometer's sketchpad dengan pendekatan konstruktivisme berbasis Teori Jean Piaget dinilai oleh siswa dengan respon positif dengan rata-rata persentase respon positif sebesar $88,88 \%$, serta respon guru dengan rata-rata persentase sebesar $84 \%$. (2) Efektif karena diperoleh hasil keterlaksanaan CD pembelajaran matematika berbantuan software geometer's sketchpad dengan pendekatan konstruktivisne berbasis teori Jean Piaget menggunakan lembar aktivitas guru dengan rata-rata persentase sebesar $89,22 \%$ dan lembar aktivitas siswa dengan rata-rata persentase sebesar $88,33 \%$, sehingga lembar aktivitas guru dan siswa dikatakan efektif. (3) Efektif karena diperoleh hasil tes hasil belajar dengan ketuntasan klasikal $84,37 \%$ sehingga CD pembelajaran matematika dikatakan efektif jika ratarata skor tes hasil belajar siswa memenuhi ketuntasan klasikal, yaitu 75\% dari seluruh siswa mendapat skor lebih besar atau sama dengan KKM.

\section{UCAPAN TERIMAKASIH}

Penulis menyampaikan terimakasih kepada Ibu Sinta Dameria Simanjuntak, S.Si., M.Pd. sebagai Dosen Pembimbing 1 dan Ibu Ribka Kariani Sembiring, S.Si., M.Pd. sebagai Dosen Pembimbing 2 yang telah mengarahkan dan membimbing penulis mulai dari awal penelitian hingga berakhirnya penelitian sehingga penulis dapat menuliskan artikel ini yang merupakan bagian dari hasil penelitian penulis. Penulis juga menyampaikan terimakasih kepada Kepala Program Studi Pendidikan Matematika, Dekan, dan Rektor

Cartesius: Jurnal Pendidikan Matematika Vol. 2, No. 2

CProdi Pendidikan Matematika Universitas Katolik Santo Thomas 
Universitas Katolik Santo Thomas atas dukungan yang diberikan kepada penulis.

\section{DAFTAR PUSTAKA}

[1] Arikunto, Suharsimin. 2010. Prosedur Penelitian Suatu Pendekatan Praktik. Jakarta: PT. Rineka Cipta.

[2] Arikunto, Suharsimin. 2013. Dasar - Dasar Evaluasi Pendidikan. Jakarta: Bumi Aksara.

[3] Arsyad, Azhar. 2013. Media Pembelajaran. Jakarta: PT Raja Grafindo Persada.

[4] Fatmawati, Agustina. 2016. Pengembangan Perangkat Pembelajaran Konsep Pencemaran Lingkungan Menggunakan Model Pembelajaran Berdasarkan Masalah Untuk SMA Kelas X. Jurnal EduSains. Volume 4, Nomor 2.

[5] Himmi,dkk. 2018. Pengembangan Modul Sistem Pertidaksamaan Dua Variabel Berbasis Geogebra Terhadap Kemampuan Visual Thinking Matematis Siswa Kelas X. Jurnal Pythagoras. Volume 7, Nomor 1.

[6] Khairani, Makmun. 2017. Psikologi Belajar. Yogyakarta: Aswaja Pressindo.

[7] Isjoni. 2011. Cooperative Learning. Bandung: ALFABETA.

[8] Kurniasari, Ferrina Dwi. \& Qohar, Abdul. 2012. Pengembangan Media Pembelajaran matematika Berbantuan Komputer pada Materi Ruang Dimensi Tiga untuk Siswa Kelas X SMA BILINGUAl. Jurnal Penelitian Matematika. Volume 1, Nomor 3.

[9] Kustandi \& Sutjipto. 2013. Media Pembelajaran Manual dan Digital. Bogor: Ghalia Indonesia.

[10] Maharani, Hevy Risqi. \& Basir, M.Abdul. 2016. Pengembangan Media CD Interaktif Matematika untuk Meningkatkan Kemampuan Pemecahan Masalah SMP.Jurnal Refleksi Edukatika. Volume 7, Nomor 1.

[11]Mudlofir, H. Ali. \& Rusydiyah, Evi Fatimatur. 2016. Desain Pembelajaran Inovatif Dari Teori ke Praktik. Jakarta: PT RajaGrafindo Persada.

[12]Nugraha. Depi Ardian. 2017. Penerapan Pembelajaran Berbasis Masalah Berbantuan Program Geometer's Sketchpad untuk Meningkatkan Kemampuan Reprentasi Multipel matematis Siswa. Jurnal Teori dan Riset Matematika (TEOREMA). Volume 1, Nomor 2.

[12] Posasi, Selva. 2015. Pengembangan CD Pembelajaran Matematika Berbantuan Software Geogebra dengan pendekatan Konstruktivisme Berbasis Teori Jean Piaget pada Materi Kubus dan Balok. AKSIOMA:Jurnal Matematika dan Pendidikan Matematika. Volume 6, Nomor 2.

Cartesius: Jurnal Pendidikan Matematika Vol. 2, No. 2

CProdi Pendidikan Matematika Universitas Katolik Santo Thomas 
[13]Prasetyawan, Agus. 2016. Pengembangan CD pembelajaran Interaktif dengan Menggunakan Model Problem Based Learning Berbantuan Software Camtasia Studio pada Materi Bilangan Bulat. AKSIOMA : Jurnal Matematika dan Pendidikan Matematik. Volume 7, Nomor 1.

[14]Rezeki \& Ishafit. 2017. Pengembangan Lembar Kerja Siswa (LKS) Berbantuan Media Simulasi Dengan Modellus Untuk Pembelajaran Kinematika Sekolah Menengah Atas (SMA). Avaliable online at: http://ejournal. Unipma. Ac. Id/index.php/snpf.

[15]Rusman. 2017. Belajar dan Pembelajaran. Jakarta: Kencana Predana Media Group.

[16]Salim \& Haidir. 2012. Strategi Pembelajaran. Medan: Perdana Publishing. [17]Santika, Satya. 2016. Pengaruh Penggunaan Pembelajaran Kooperatif tipe STAD Berbantuan Program Geometer's Sketchpad Terhadap Kemampuan Berpikir Kreatif Matematik Siswa SMP. Jurnal Penelitian Pendidikan dan Pengajaran Matematika. Volume 2, Nomor 2.

[18]Saputri, Afnur \& Nelmira, Weni. 2019. Pengembangan CD Interaktif Berbasis Tutorial Mata Kuliah Gambar Anatomi Mahasiswa Tata Busana Jurusan IKK FPP UNP. Gorga Jurnal Seni Rupa. Volume 8, Nomor 1.

[19]Soemarmo, Utari. 2014. Penelitian Pembelajaran Matematika. Bandung: PT RefikaAditama.

[20]Sudjana, Nana. 2016. Penelitian Hasil Proses Belajar Mengajar. Bandung: PT Remaja Rosdakarya Offset.

[21]Sugiyono. 2015. Metode Penelitian Pendidikan. Bandung: Alfabeta.

[22]Susanto, Ahmad. 2014. Teori Belajar dan Pembelajaran. Jakarta: Prenada Media Group.

[23]Tampubolon, Saur. 2014.Penelitian Tindakan Kelas Sebagai Pengembangan Profesi Pendidikdan Keilmuan. Jakarta: Erlangga.

[24]Trianto.2011. Mendesain Model Pembelajaran Inovatif - Progresif. Jakarta: Kencana Prenada Media Group.

[25]Wardoyo, Mangun. 2013. Pembelajaran Konstruktivisme. Bandung: Alfabeta.

[26]Wijaya, Indra. \& Tanjung, Faisal. 2017. Perancangan Dan Pembuatan Media Pembelajaran CD Interaktif Berbasis Macromedia Director MX Pada Mata Pelajaran Pemrograman Web Dinamis. Jurnal Pendidikan dan Teknologi Informatika. Volume 4, Nomor 2.

Cartesius: Jurnal Pendidikan Matematika Vol. 2, No. 2

CProdi Pendidikan Matematika Universitas Katolik Santo Thomas 